日消外会誌 $12(5): 296 \sim 302,1979$ 年

\title{
食道癌食道切除後に併発した乳糜胸の治療
}

\author{
* 癌研究会附属病院外科 \\ **同頭顠部科 \\ 大橋 一郎* 松原 敏樹 木下 䈨 \\ 高木 国夫 梶谷 鐶 内田 正興**
}

\section{TREATMENT OF CHYLOTHORAX FOLLOWING ESOPHAGEAL RESECTION FOR CARCINOMA OF THE ESOPHAGUS}

\section{Ichiro OHASHI*, Toshiki MATSUBARA, Iwao KINOSHITA, Kunio TAKAGI, Tamaki KAJITANI and Masaoki UCHIDA,**}

Cancer Institute Hospital

*Department of Surgery

**Department of Head and neck

\begin{abstract}
食道癌切除時にわれわれは根治性拆大のために胸管切除を行っている.1978年12月までに切除した食道 癌360例中に術後乳糜胸の合併症を起こしたものは 8 例 (2.2\%) であった．6例に再開胸を行い，5ち 3 例に胸管より乳糜漏出を確認結紮し治窑した. 再開胸によるも漏出部不明の 3 例では胸管を結禁し，らち 1 例は再開腹によりさらに大動脈周囲のリンパ管を結禁した. 再開胸は乳糜漏出不明の場合にも胸胝ドレ ナージを確実に設置することが出来, 再開胸の 6 例中 1 例が 呼吸不全で死亡した他は，予後良好であっ た. 非開胸の 2 例は，胸腔ドレナージで治瘺した．乳糜胸の発症時期を術後 4 日までの早期型と 7 日以後 の晚期型に分けてみると, 早期型では胸管からの直接漏出を確認しうる場合があって, 積極的に再開胸を すべきであり，晚期型では適切な胸腔ドレナージで治癒する症例もあり，乳糜量を考慮し，全身状態を観 察することにより，再開胸の適応を考慮したい。
\end{abstract}

索引用語：食道癌切除後合併症，乳糜胸，胸管結焚

はじめに

乳糜胸の発生は外傷性と非外傷性にわけられるが，近 年胸部手術例が増加し，とくに食道癌の食道切除後の合 併症として，頻度は低いが乳糜胸を認めることがある。 食道癌で食道切除後の乳糜胸の発生頻度は三富ら" は 1 \%とのべている.ひとたび乳糜胸を起こすと非常に厄介 なもので，時に致命的ですらある.

癌研外科において，われわれは，胸部食道癌の手術に 際し，根治性拡大のため胸管切除を行っているが，食道 癌切除後の乳糜胸を 8 例経験したので報告し，治療の面 に検討を加えた。

\section{頻 度}

1946年から1978年12月までに癌研外科で行った食道癌
切除360例の中, 乳糜胸は8 例 $(2.2 \%)$ であった. 原病巣および術式 (表 1).

8 例 に括ける食道癌主占拠部位は $\mathrm{Ce} 2$ 例，Iu 2 例, Im 4 例であり, 肉眼癌型は潰瘍限局型 3 例, 潰瘍 漫潤型 3 例, 潰瘍中間型 1 例, 腫㿔様 I 型の癌肉腫 1 例 であった，癌が全周性に存在するものが 6 例と多かっ た. 外膜浸润度は $A_{0} 4$ 例， $A_{1} 1$ 例， $A_{2} 2$ 例，気管へ 浸潤した $A_{3} 1$ 例であった.リンパ節転移陰性が 4 例， 転移陽性は 4 例であった。

食道癌に対する手術々式は 8 例中 7 例が右開胸食道亜 全剔で，術後右乳糜胸を認め，他の 1 例 (No. 7) 梳胸 骨柄切除を伴う. 頝部, 胸部上部食道切除を施行し, 術 後左乳糜胸を認めた。 
表 1 . 食道癌食切後乳糜症例

\begin{tabular}{|c|c|c|c|c|c|c|}
\hline No. & 年齢 & 性 & 原 病 巣 & 術 式 & $\begin{array}{l}\text { 乳糜胸 } \\
\text { 発症日 }\end{array}$ & 乳糜量/日 \\
\hline 1 & 63 & q & $\begin{array}{l}\mathrm{Ce}-\mathrm{Iu}(\text { 周), } 13 \mathrm{~cm} \text {, 潰浸, } \\
\text { Ao.n }(9 / 11) \text { 壁内 meta }\end{array}$ & 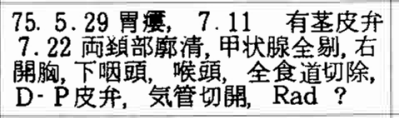 & 2 pod & $800 \mathrm{ml}(\mathrm{r})$ \\
\hline 2 & 77 & $\hat{\delta}$ & $\begin{array}{l}\text { Iu (右, 全周), } 2.3 \times 2.5 \\
\text { 潰限, } \mathrm{A}_{3} \text { (trachea), n }(4 / 6)\end{array}$ & $\begin{array}{l}70.5 .1 \text { 胃㷬, } 5.11 \text { 右開胸食切, } \\
\text { 禹鎖上廓清， Pall. }\end{array}$ & 3 & $1400(r)$ \\
\hline 3 & 66 & $\delta$ & $\begin{array}{l}\mathrm{Iu}(\text { 周), } \\
\text { 潰限 (中), } \mathrm{A}_{0} \cdot \mathrm{A} \times \mathrm{n}(5 / 21)\end{array}$ & $\begin{array}{l}\text { 68. } 7.19 \text { 胃噻, } 7.29 \text { 右開胸食切, } \\
\text { Rad. } 9.18 \text { 胃管挙上, } 10.9 \text { 食 } \\
\text { 胃吻合 }\end{array}$ & 4 & $700 \sim 1000(r)$ \\
\hline 4 & 69 & tิ & $\begin{array}{l}\operatorname{Im}(\text { 前 }), \quad 4.0 \times 2.0 \\
\text { polypoid I 型 }(\mathrm{sm}), \mathrm{n}(0 / 10) \\
\text { Carcino Sarcoma }\end{array}$ & 75. 7.30 右開胸食切, 胃掼, $\mathrm{Rad}$ & 4 & $850(r)$ \\
\hline 5 & 69 & $\delta$ & $\begin{array}{l}\operatorname{Im}(\text { 右, 全周), } 6.0 \times 6.0 \\
\text { 潰限, } \mathrm{A}_{2} . \mathrm{n}(0 / 24)\end{array}$ & $\begin{array}{l}\text { 75. } 11.10 \text { 縦隔鏡, 右開胸開腹食妇 } \\
\text { 胃管挙上, Rad. } 12.8 \text { 食胃吻合 }\end{array}$ & 7 & $250 \sim 1000(r)$ \\
\hline 6 & 69 & 우 & $\begin{array}{l}\operatorname{Im}(\text { 右, } 1 / 2 \text { 周) }, 2.5 \times 2.5 \\
\text { 潰浸, } \mathrm{A}_{0} . \mathrm{n}(0 / 28)\end{array}$ & 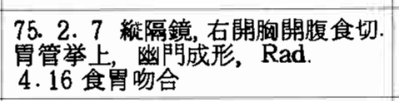 & 10 & $2100(r)$ \\
\hline 7 & 67 & 우 & $\begin{array}{l}\mathrm{Ce} \text { (周), } 5.0 \times 2.5 \\
\text { 浊浸 } \mathrm{A}_{2} . \quad \mathrm{n}(9 / 22)\end{array}$ & 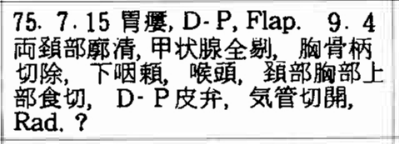 & 7 & $300(1)$ \\
\hline 8 & 63 & กิ & $\begin{array}{l}\text { Im-Ei (周), } \quad 10.4 \times 5.0 \\
\text { 潰中+II c, } A_{1} . n(0 / 31)\end{array}$ & $\begin{array}{l}\text { 78. } 9.27 \text { 開腹右開胸閏腹食切, 胃 } \\
\text { 管挙上 }(\text { 胸愲後) 幽門成形, Rad. }\end{array}$ & 12 & $800 \sim 1400(r)$ \\
\hline
\end{tabular}

C. I.H. 1979. 2 .

図 1，食道切除後右乳糜胸（症例 6)

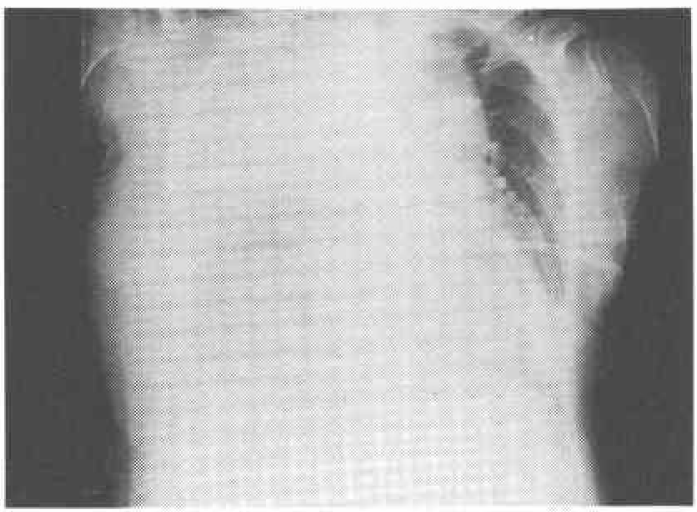

\section{乳糜胸の発症日および乳糜量}

食道切除後の乳糜胸の発症は術後 4 日以内が 4 例と半 数を占め，10日後に 発生したものは 2 例で，最短 2 日 目，最長12日目であった。乳糜の 1 日の吸引量は $250 \mathrm{ml}$ から多いもので1,400ml に達した。

図 1 は, 症例 6 の食道切除後の右乳糜胸で, 図 2 は, 右再開胸後, 右胸腔ドレナージ施行中の状態である.

乳糜胸の誘因（表 2 ）
図2.右再開胸後右胸腟ドレナージ施行中（症例 6)

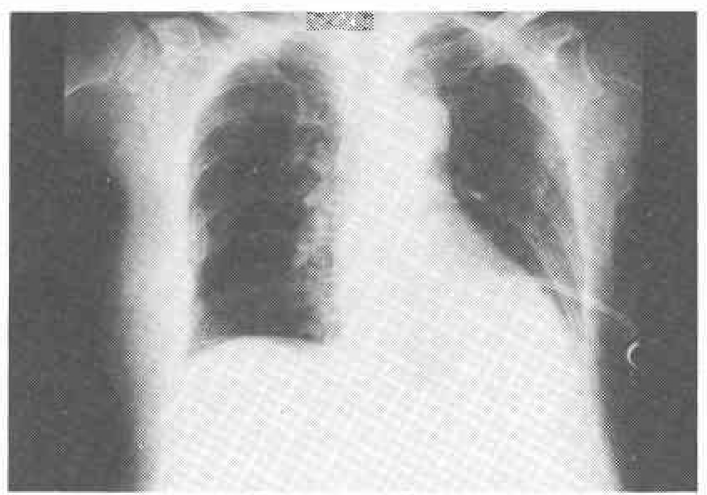

乳糜胸の誘因を見ると，食道癌切除時胸管の結紮切除 を行ったものは8例中 6 例で, 結禁切除部は, 2 例が中 部食道，4例が下部食道であった。症例 7 を除いた 7 例は，気管分岐部から傍気管，上部傍食道まであるい は,ボタローから左肺門まで広範なリンパ節廓清が行わ れて㧍り, その際, 胸管から Collateral way を損傷し たと推測された。

乳糜胸に対する右再開胸術所見 
表 2. 乳糜胸誘因と再開胸所見

\begin{tabular}{|c|c|c|}
\hline No. & 乳糜胸誘因 & 乳糜胸再右開胸術所見 \\
\hline 1 & 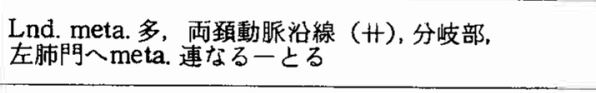 & 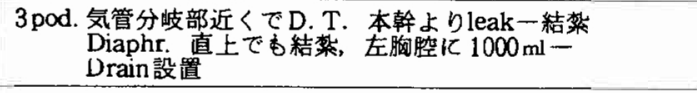 \\
\hline 2 & 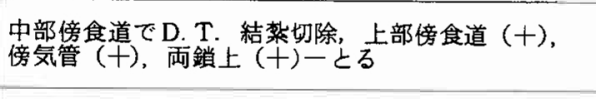 & 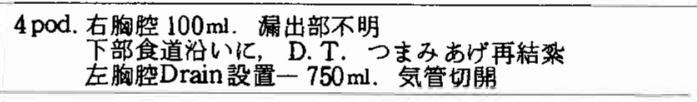 \\
\hline 3 & 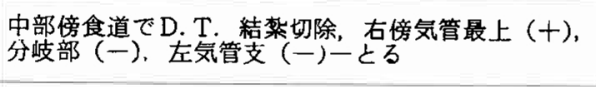 & $\begin{array}{l}4 \text { pod. 右胸曌 } 500 \mathrm{ml} \text { Th. X X 高さでAorta近くより乳糜でる } \\
\text { D. T. } 5 \mathrm{~cm} \text { 切除し結慗 }\end{array}$ \\
\hline 4 & $\begin{array}{l}\text { 下部傍食道でD.T. 結架切除，傍気管最上 }(-), \\
\text { 分㟝 }\end{array}$ & 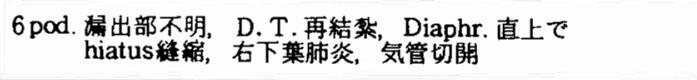 \\
\hline 5 & 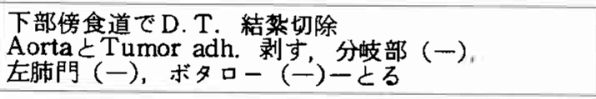 & OPせす \\
\hline 6 & 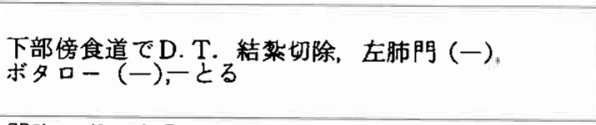 & 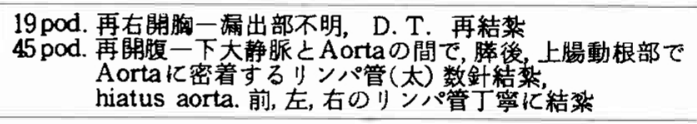 \\
\hline 7 & $\begin{array}{l}\text { 開胸せず，胸骨柄切除し胸部上部食道 } \\
3 \mathrm{~cm} \text { 切除 }\end{array}$ & 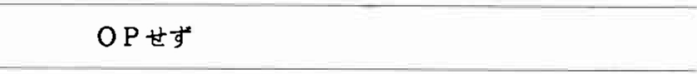 \\
\hline 8 & 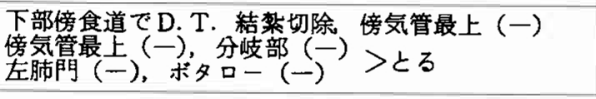 & 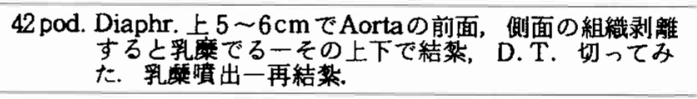 \\
\hline
\end{tabular}

乳糜胸に対して右再開胸を施行したものは6例で, 症 例 $1 ， 3 ， 8$ の 3 例は乳糜の漏出部を確認しえた。症例 1 は食道切除後 2 日目に乳糜胸を認め翌 3 日目に右開胸 を施行し，気管分岐部近くで，胸管本管より乳糜の漏出 を認め，これを結帒，さらに横隔膜直上に扮いても大 動脈に沿ったリンパ管を結禁した。左胸腔にも乳糜を $1,000 \mathrm{ml}$ 認めたので左胸腔にもドレーンを設直した. 再 手術後の乳糜量は右胸胿から $500 \mathrm{ml} /$ 日, 左胸腔から100 〜 300 ml/日と急減した，症例 3 は右再開胸時，第 10 胸椎 の高さで大動脈近くより乳糜の流出を確認, 胸管を $5 \mathrm{~cm}$ 切除して結禁した. 術後乳糜の漏出は100〜200 $\mathrm{ml} /$ 日と 激隇した. 症例 8 は，食道切除後12日目に右乳糜胸を認 め保存的に治療してきたが，食事を摂取すると乳糜量が 増加し，42日目に右再開胸施行し，横隔膜上 $5 \sim 6 \mathrm{~cm}$ の 部位にて大動脈の前面掞よび側面の組織を剝離すると， その中より術前に飲んでいた牛乳がにじみ出るのを認め た.胸管を確認し胸管に切開を加えると牛乳が噴出した ので胸管を再結禁した。術後の乳糜漏出は 1 日 $150 \mathrm{ml}$ らいと減少し, 再開胸後 3 日目より経口的食事摂取を開 始し， 5 日目には胸腔からの吸引量は $20 \mathrm{ml}$ となり胸腔 ドレーンを抜去した。症例 $2 ， 4,6$ の 3 例では, 右再 開胸により胸管切断端を確認したが異常なく, 乳糜の漏 出部を認めえなかったが，胸管を再結紮した。症例 4 で
因3.右乳糜胸再開胸術後ドレナージ施行中 (症例 4)

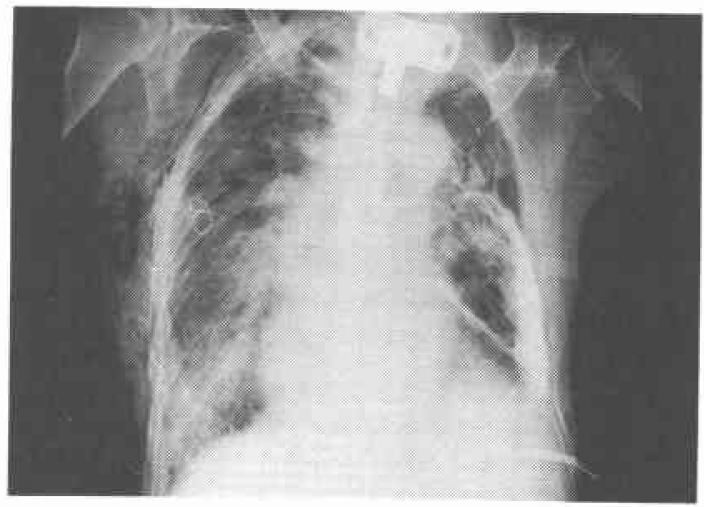

は，さらに横隔膜の直上で，大動脈裂孔の周囲を縫縮し た，症例 2 ．および 4 は術後乳糜量が減少したが，症例 6は減少しなかった．本例の経過については後述する。 症例 4 は，結核に上り左肺機能が悪く，右乳糜胸及び肺 炎を併発して再開胸の翌日呼吸不全で死亡した（図 3） が，他の 7 例は治癒した。

\section{乳糜胸の治療経過（表 3)}

治療経過を見ると症例 5,7 の如く，再開胸を行わな かった 2 例は，持続胸韍ドレナージのみにて食道切除後 
表 3. 乳糜胸症例治療経過

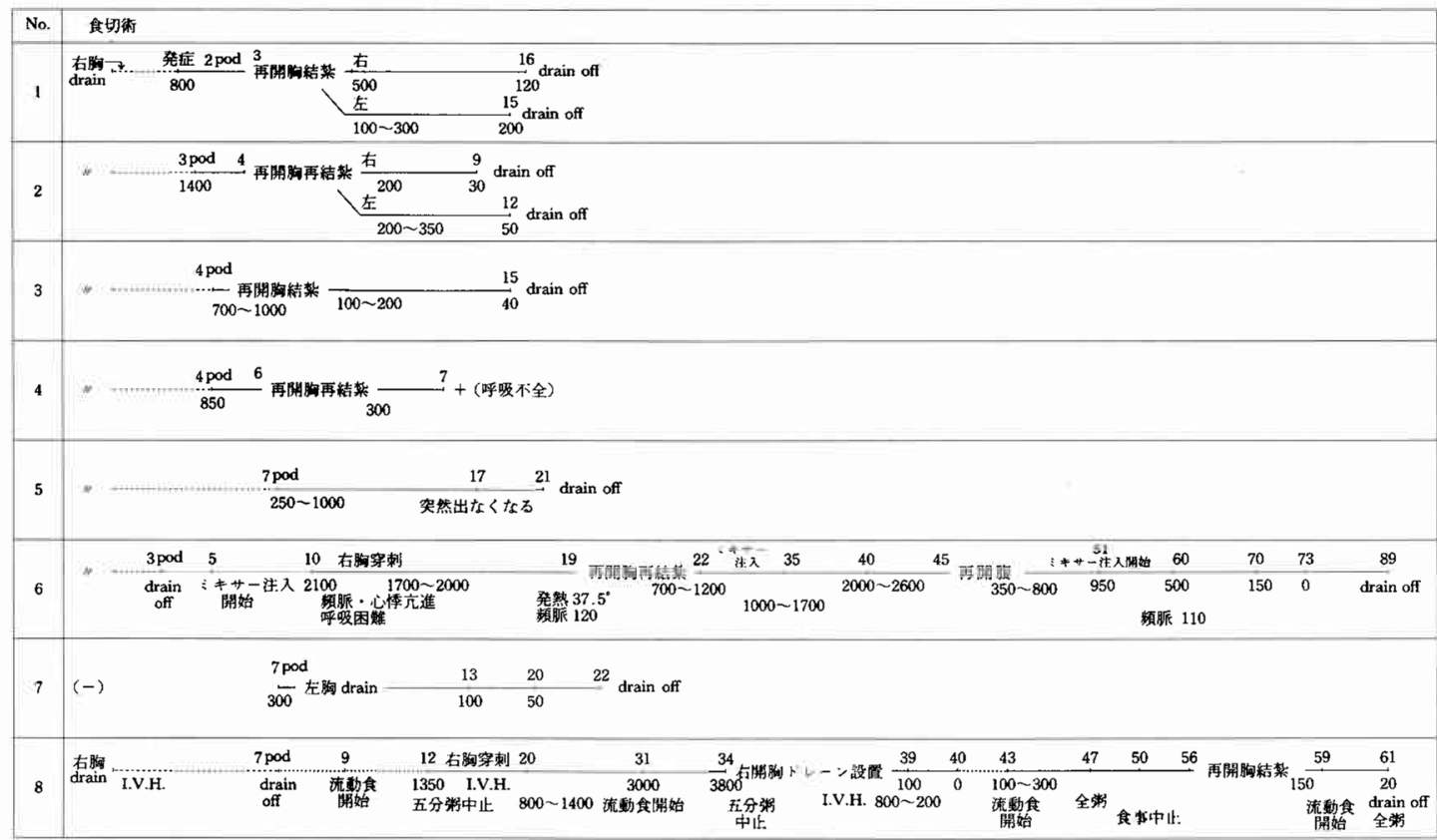

17日と20日に自然に治癒した. 再開胸後の症例 $1 ， 2$ ， $3 の 3$ 例も, 再開胸前 $700 \mathrm{ml}$ から1,400ml も流出した乳 糜が術後 $200 \mathrm{ml}$ から $300 \mathrm{ml}$ 位となり，16日以内にドレー ンを拔去している。

症例 6 は乳糜発症が遅く, ミキサー食を注入開始後の 10日目に頻脈, 心悸六進, 呼吸困難と共に乳糜を1,700 $2,000 \mathrm{ml}$ 認め, 右胸腔穿刺を繰返したが効果なく19日目 に再開胸により精査した. 乳糜漏出部は不明であったが 胸管を再結禁した．その後も胸腔ドレーンより $700 \mathrm{ml}$ か ら1,200ml の排液が続き，ミキサー食の注入を開始す ると 1 日に $2,000 \mathrm{ml}$ から $2,600 \mathrm{ml}$ と乳糜が増量する為 I.V.H. を併用していたが食道切除後45日目に再開腹を 行った。下大静脈と大動脈との間で, 膵後部, 上腸間膜 動脈根部で大動脈に密着するリンパ管が怒張して㧍り， これを結紫, さらに 横隔膜下で大動脈裂孔の前, 左, 右の太いリンパ管を丁寧に結禁した. 開腹術後乳糜量 は $350 \mathrm{ml}$ から $800 \mathrm{ml}$ になり，ミキサー食を注入してむ $950 \mathrm{ml}$ 位であったがその後排液量は次第に減少し73日目 に治瘾した。

症例 8 は, 右開胸食道切除後 7 日目に胸腔ドレーンを 抜去し，9日目に流動食の経口的摂取を開始した。12日 目に 5 分粥を摂取していたが，右胸腔に乳糜の貯留を認
めた. 食事摂取を中止し I.V.H. 併用にて, 右胸腔穿刺 を絽返し 1 日に $800 \mathrm{ml}$ から1,400mI の乳糜を認めた。 術後31日目に流動食摂取を開始すると胸腔穿刺にて乳糜 の漏出が3,000ml から3,800ml と増量し，34日目に胸 隺ドレーンを設置した。 I.V.H. 併用にて, 乳糜は1日 $800 \mathrm{ml}$ 認められたが次第に1日量が減少し39日目には $100 \mathrm{ml}$ となり，40日目には，胸腔ドレーンからの排液が 無くなった．経口的に食事摂取を開始すると再び乳糜量 は $100 \mathrm{ml}$ から $300 \mathrm{ml}$ 認められるようになり食事摂取を中 止したが乳糜漏出が続き食道切除後56日目に右再開胸に より乳糜漏出部および胸管結禁を行い, 食道切除後 61 日 目に治癒した。

\section{乳糜胸の治療方針}

乳糜胸の 8 例に対する経験から食道切除後 7 日以上経 過して，乳糜胸を生じたものでは，胸腔ドレナージにて 術後17日から20日頃までた自然治癒する症例すあった が，なお，乳糜量の減少しないるのは，再開胸にて胸管 を確認し結紮し適切なるドレナージを設置するととも に, 再開腹も試みる必要があった。食道切除後 2 日から 4 日目に発症した乳糜胸は胸管から直接漏出する症例も あり, 乳糜量が 1 日700 ml から800 ml 以上あれば, 積 極的に再開胸を行って漏出部を確認し，また，漏出部不 
明の場合にも胸腔ドレナージを確実に設置することが出 来，予後が良好であった。

\section{考察}

外傷性乳糜胸についての報告は多いが，手術後に発生 した乳糜胸については Lampson" (1948) は18例中 4 例 $(22.2 \%)$ Goorwitch $^{2)}$ (1955) は31例中13例 (41.9\%) と報告し，この時点の集計で90例中18例 (20.0\%) と述 ベている．本邦報告例では，山本 ${ }^{3)}$ (1967) が術後乳糜 胸を集計し23例中 5 例 $(21.7 \%)$ ，三富 ${ }^{4)}$ (1973) は37 例中14例 $(37.8 \%)$ を集計し外科手術後の症例報告が続 いたため実際の原因別頻度より高くなったのであろうと のベている．食道切除後の乳糜胸については報告が少な い.

Bressler $^{5)}$ (1953) が左開胸食道切除後の乳糜胸に, 胸 腔ドレナージにより治瘉 せしめた例を報告し Schoen ${ }^{6)}$
（1968）は術後乳糜胸101例中，食道手術に由来する のは8例 $(7.9 \%)$ と述べている.

本邦例では，石合 ${ }^{7)}$ (1965) が食道癌根治切除後の 2 例に乳糜胸を認め穿刺排液により各々24日および30日で 治癒したと報告している．石合）（1968）はまた，アカ ラジに対し, Heller 手術後の症例に再開胸, 胸管結 禁を施行し41日にて治癒した例を述べている．佐藤 （1968）は食道癌根治術後の乳糜胸にドレーン排液を行 い，治癒し得た症例を報告している．三富 ${ }^{4)}$ （1968） は, 食道癌切除例総数 285 例中乳糜胸の 3 例 (1.0\%) を 報告し, 穿刺排夜にて10カ月後に治癒した例と, ドレ一 ン排液にて21日後に治癒せしめた 1 例及び, 再開胸, 胸 管結禁後 2 日目に急性心停止にて死亡した症例を報告し ている、乳糜胸の死亡率は Shackelford ${ }^{10)}$ (1938) によれ ば，非開胸例の死亡率は50\%であり Lampson" (1948)

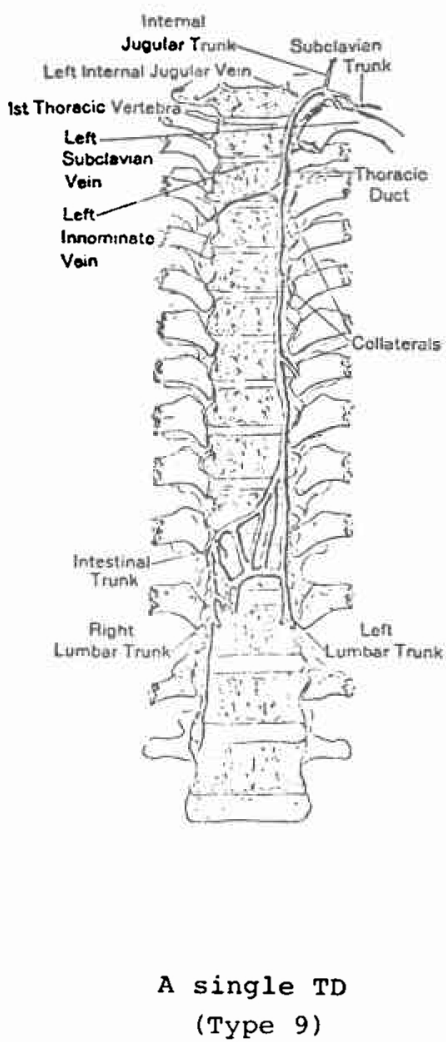

(Davis,I9I5)
図4.

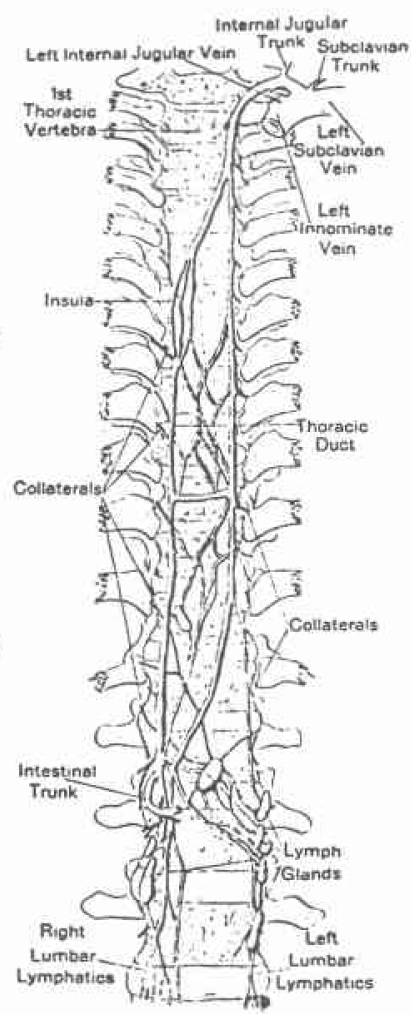

Duplication of TD

(Type 1)

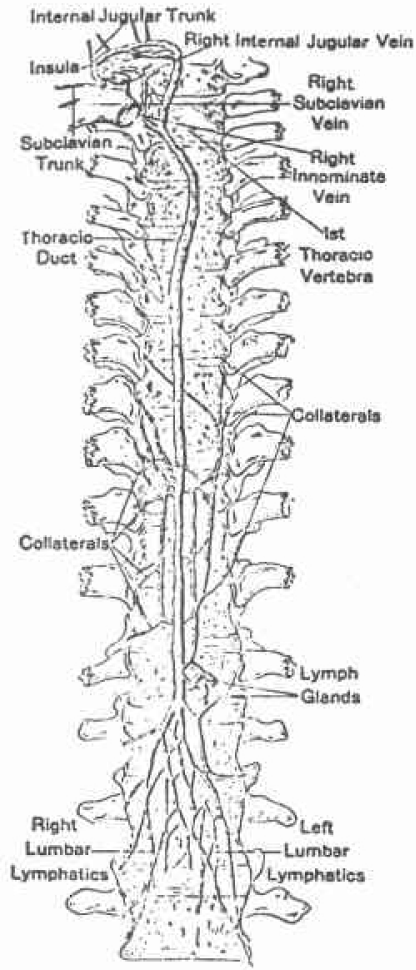

A single TD emptying into right vein

(Type 8) 
の集計時には45\% (58例中26例) であった.しかし Lampson が開胸による胸管結禁術を 1 例施行して以来 死亡率は低下した，Goorwitch ${ }^{2)}$ （1955）は，胸管結禁 術を15例施行し死亡例はなく，手術しなかった16例では 死亡率 $19 \%$ ，全体の死亡率は10\%と報告している. 本邦 では死亡例は三富らにより報告されているが，われわれ の症例では 8 例中 1 例が再開胸後に呼吸不全で死亡して いる. 本死亡例は術前から結核による左肺機能障害が高 度であって胸腔ドレナージの適応を考慮すべきであった と考える. Selle ${ }^{11)}$ (1973) は，非外傷性乳糜胸には手 術の効果がなく外傷性のものでも，まず非観血的に排液 すべきであると述べている，Maloney ${ }^{12)}$ (1956) は, 13例の心血管手術後の乳糜胸に対し，11例 $(84.6 \%)$ が 頻回な穿刺排液による自然修復を待つ方法により平均 21 日にて治瘺している．外傷性乳糜胸に対して手術に踏み 切る規準として， Selle はまず胸㚙穿刺执よびドレナー ジを行い 2 週間経って乳糜が隇少しない場合や，成人で $1,500 \mathrm{ml} /$ 日以上，小児で年秢 $\times 100 \mathrm{ml} /$ 日以上の乳糜流出 が 5 日間続く場合，また，栄養障害を来たす場合には開 胸が必要であることを述べている．われわれは食道切除 後の乳糜漏出の発症時期を 2 日から 4 日の早期発症型と 7 日以後の晚期発症型に分け検討した. 乳糜の早期発症 型のものでは胸管からの直接漏出を確認しうる場合もあ って，積極的に再開胸を行い，漏出部を確認することが 必要と思われる. 晚期発症型のものでは適切なる胸腔ド レナージにて自然治癒する症例むあり乳糜量を考慮し， 全身状態を観察しつつ再手術の適応を考皃たい. Davis ${ }^{13)}$ （1915）[図 3]によれば，胎生学的見地から胸管を，9 種類に分類（図4）しているが，われわれも近年胸管造

図 5.胸管造影 (正面) Davis の分類の Type 9 に 相当する

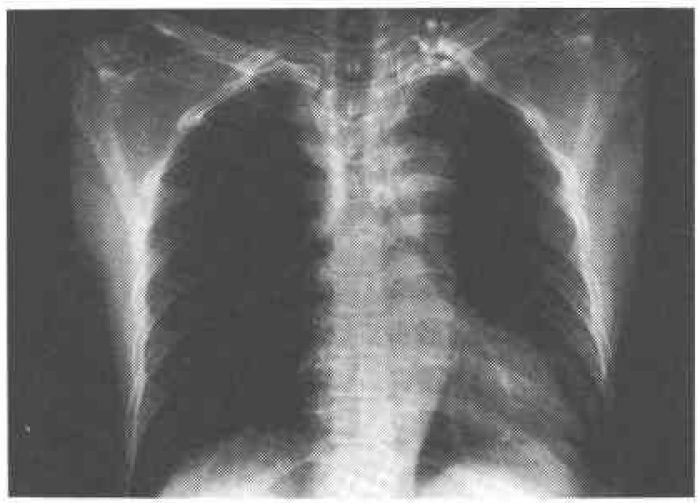

影を行って Variation を検索中である．図5，6は61歳 男性で Iu から Im にかけて長径 $16 \mathrm{~cm}$ の鋸歯型食道癌 で気管および左気管支㾞が著明で食道切除不能の症例の 胸管の走行を示したものである．胸管は 1 本で食道裂孔 部では大動脈の右後方を上行し，第 9 胸椎辺りの高さ で左に曲って上行し，左鎖骨下静脈に合流している. Davis の分類の Type 9 に相当し Left branch が存在し right branch が造影されず,これは癌の浸潤により閉塞 したのか先天的に欠損しているのか不明である. Eung Man $\mathrm{Cha}^{14)}$ (1976) の報告によれば，胸管の走行に関し

図 6 ，胸管造影（第 1 斜位）

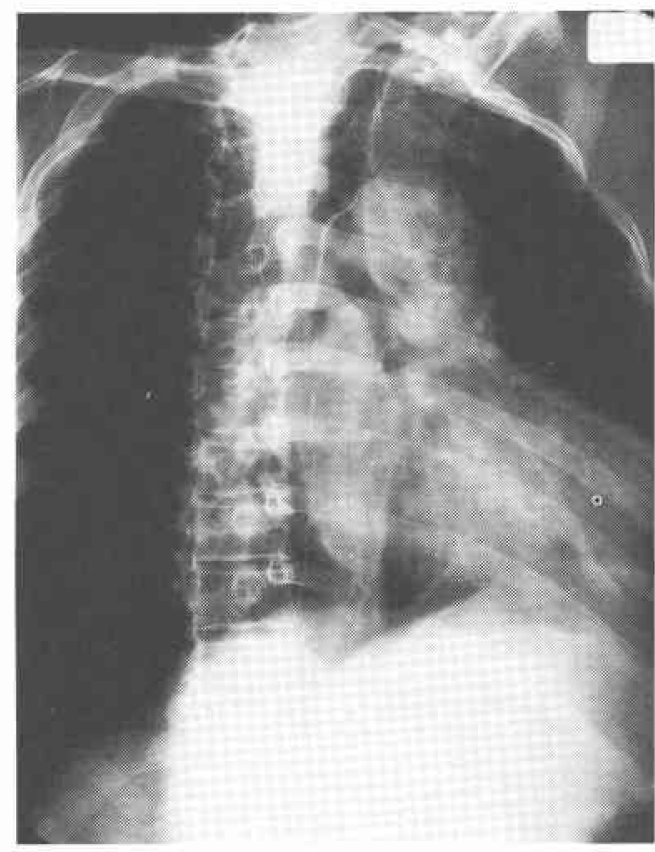

表 4. Classification of TD variation (65 cases)

1. A single TD emptying into right vein

2. Duplication of TD

a. Complete duplication

b. Incomplete duplication $\mathrm{Y}$-shaped thoracic duct Inverted Y-shaped TD

Segmental plexus formation Upper third Middle third Lower third

4. Multiple plexus formation With main duct Without a main duct 2 cases 19 6

2 cases
9
6
3
7
6
33
9
3
1
1
6
5

(E. M. Cha et al., 1976) 
て243例中65例 $(26.8 \%)$ に解剖学的変異があり，右の 鎖骨下静脈に合流する右側終末型 2 例, 重複型19例, 部 分的リンパ叢形成するるの13例，多発りンパ叢形成する もの11例と報告している（表 4). 乳糜胸の原因がこれ ら胸管の解剖学的走行異常による場合もあるので, 食道 癌に対する手術時にも胸管の走行に注意する必要があ る.

\section{結 語}

われわれは食道癌切除時に根治性払大のため胸管切除 を行っている．1978年12月までの食道癌切除例360例の 合併症例中，乳糜胸は 8 例， $2.2 \%$ であった．6例に再 開胸を行い3 例に胸管よりの乳糜漏出を確認しえた。漏 出部不明例の 3 例には胸管を結禁し，うち 1 例は，再開 腹によりさらに大動脈周囲のリンパ管を結禁した。漏出 部不明の場合も, 胸腔ドレナージを確実に設置すること ができ，予後良好であった。

（要旨は, 第 7 回日本消化器外科学会大会にて発表し た.)

\section{文献}

1) Lampson, R.S.: Traumatic chylothorax; A Review of the literature and report of a case treated by mediastinal ligation of the thoracic duct. J. Thoracic. Surg., 17: 778-791, 1948.

2) Goorwitch, J.: Traumatic chylothorax and thoracic duct ligation. J. Thorac. Surg., 29: $467-479,1955$.
3) 山本浩他：肺癌術後に併発した乳糜胸の 1 症 例.癌の臨床, 13 (9) : 682-688, 1967.

4) 三富利夫他：術後の乳糜胸。外科診療, 15 : 288-296, 1973

5) Bressler, S., et al.: Traumatic chylothorax following esophageal resection. J. Thoracic Surg., 26: 321-324, 1953.

6) Schoen, H.R.: Der Chylothorax. Thoraxchirurgie, 16: 444-448, 1968.

7) 石合省三他：術後乳糜胸 の 2 例飞ついて。外 科, $27: 535-539,1965$.

8）石合省玔他：手術的に治療せしめ兄大乳糜胸の 1 例. 外科, $30 ： 976-979,1968$.

9）佐藤博他：食道癌術後乳糜胸の 1 例。日胸外 会誌, $16: 811,1968$.

10) Schackelford, R.T. and Fisher, A.M.: Traumatic chylothorax. South M.J., 31: 766-775, 1938.

11) Selle, J.G. et al.: Chylothorax, indications for Surgery. Ann. Surg., 77: 245-250, 1973.

12) Maloney, J.V., et al.: The nonoperative treatment of traumatic chylothorax. Surgery, 40: 121-128, 1956.

13) Davis, H.K.: A statistical study of the thoracic duct in man. Amer. J. Anat., 17: 211-244, 1915.

14) Eung Man Cha and Sirijintakarn, P.: Anatomic variation of the thoracic duct and Visualization of mediastinal lymph nodes. Radiology, 119: 45-48, 1976. 